\title{
畳み込み符号化プリコーデッドOFDMの繰り返し復調方式
}

\section{Iterative Detection of Pre-coded OFDM Combined with Convolutional Code}

\author{
宮坂 宏 明 ${ }^{\dagger}$, \\ 増田陽子†, \\ 藤 井雅 弘 $^{\dagger \dagger}$, 正会員 伊丹 誠 ${ }^{\dagger}$ \\ 大 野 光 平 ${ }^{\dagger}$,
}

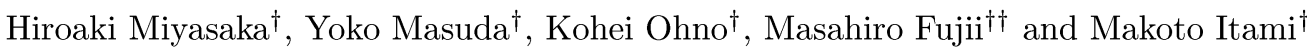

\begin{abstract}
A digital modulation scheme, OFDM, multiplexes many orthogonaly arranged sub-carriers and use spectrum efficiently. However, its performance is degraded under environments with severe multipath fading. The use of a previously reported, iterative detection of pre-coded OFDM scheme is proposed. Furthermore, the results of a computer simulation confirmed good performance. We present our analysis of the performance of iterative detection of pre-coded OFDM combined with convolutional code. The results of the simulation show that our scheme, performed better under severe fading than the conventional scheme did.
\end{abstract}

キーワード：OFDM, プリコーデイング,シンボル入れ替え, 繰り返し復調，畳み込み符号

\section{1. ま え がき}

OFDM(Orthogonal Frequency Division Multiplexing) は地上デジタル放送や無線 LAN などに用いられている変 調方式であり，直交する多数の搬送波を用いているため，周 波数スペクトルの形が矩形に近く，限られた周波数帯域を 有効に利用できる。また，ガードインターバルの付加によ り，マルチパスによって生じるシンボル間干渉を軽減する ことができる。しかし，マルチパスによる電力の落ち込み (ディップ）により，バースト誤りが発生する場合，OFDM 伝送の受信特性は劣化してしまう ${ }^{1) \sim 3)}$. この問題の対策と して，誤り訂正符号や複数のアンテナを用いたダイバーシ ティ技術など，様々な方式が提案されている ${ }^{4) \sim 9)}$. それら の中で，直交変換を用いて事前にデータシンボルの変換を 行うプリコーデッド OFDM は有効な方式である.プリコー デッド OFDM は，誤り訂正符号のように圥長ビットを付 加する必要がないため, 伝送速度の低下なしにディップの 影響を改善できるという利点がある。

筆者らは，すでにプリコーデッド OFDM において繰り 返し復調を行うことによって，劣悪なマルチパス環境下で 特性を大幅に向上できることを示している ${ }^{10)}$.しかしプ

2009 年 10 月 13 日受付, 2010 年 3 月 8 日再受付, 2010 年 5 月 18 日採録 †東京理科大学 基礎工学部

（广 278-8510 野田市山崎 2641，TEL 04-7122-1247)

†十宇都宮大学 工学部

( T 321-8585 宇都宮市陽東 7-1-2, TEL 028-689-6004)

$\dagger$ Department of Applied Electronics, Tokyo University of Science (2641, Yamazaki, Noda, Chiba 278-8510, Japan)

$\dagger \dagger$ Faculty of Engineering, Utsunomiya University (7-1-2, Yoto, Utsunomiya, Tochigi 321-8585, Japan)
リコーディングの繰り返し復調方式では，多数回の繰り返 し処理が必要である。そこで本論文では，プリコーデッド OFDM の繰り返し復調方式に誤り訂正符号を適応した効 果について検討を行う。そして，プリコーディングの繰り 返しとともに，誤り訂正符号も繰り返す復調方式を提案す る。計算機シミュレーションにより，少ない繰り返し回数 で充分な BER 特性の改善が得られることが示された。

\section{2. プリコーデッド OFDM と繰り返し復調}

プリコーデッド OFDM における送信信号 $s(t)$ は以下の 式で表される。

$$
s(t)=R e\left[\sum_{n=0}^{N-1} D_{n} e^{j 2 \pi\left(f_{c}+n f_{0}\right) t}\right]
$$

ここで， $N, f_{0}, f_{c}$ はそれぞれ搬送波数，搬送波間隔，最 小の搬送波周波数を表わす。また， $D_{n}$ はデータシンボル $d_{k}$ をプリコーディングすることによって得られるシンボル (以下プリコーデッドシンボルと呼ぶ) であり, 以下の式で 表される。

$$
D_{n}=\sum_{k=0}^{N-1} u_{n, k} d_{k} \quad(n=0,1, \cdots, N-1)
$$

(2) 式において, $u_{n, k}$ はプリコーディングを決定する定数で あり, Walsh Hadamard 変換などの直交変換行列の要素に 対応する。データシンボル $d_{k}$ は QPSK や QAM で変調さ れた複素シンボルである。受信機では，通常の OFDM 受 信機と同様に FFT 処理によって各搬送波で伝送されたプ リコーデッドシンボルが抽出され, 伝送路等化の後, 逆プ リコーディングによってデータシンボルが復調される。こ 
れによって, 最終的に復調されるデータシンボルにおいて は, 信号対雑音比が均一化され，マルチパスで生じた深い 周波数選択性フェーディングの影響を軽減可能である。し かしながら, 単純にプリコーディングと逆プリコーディン グを行う復調処理では, 付加雑音が大きくなると特性が劣 化するため, 文献 10) では受信機において繰り返し復調処 理を行い悪条件下での特性を大幅に改善する方式が提案さ れている。以下にその概要を説明する。

(1) 式の信号が伝達関数 $H(f)$ の伝送路を通って受信さ れた場合を考える. 受信機では FFT 処理によって各搬送 波で伝送されているプリコーデッドシンボルが抽出される. $n$ 番目の搬送波に対応する FFT 出力を $X_{n}$ とし, 伝送路 特性が既知としてゼロフォーシング等化を行うことによっ て, $n$ 番目の搬送波で伝送されたプリコーデッドシンボル の推定值 $\hat{D}_{n}(0)$ が得られる.

$$
\hat{D}_{n}(0)=X_{n} / H_{n}
$$

ただし,$H_{n}=H\left(f_{c}+n f_{0}\right)$ である. $\hat{D}_{n}(0)$ を逆プリコー ディングすることによって, データシンボルの推定值 $\hat{d}_{k}(0)$ が得られる。

$$
\hat{d}_{k}(0)=\sum_{n=0}^{N-1} u_{n, k}^{*} \hat{D}_{n}(0)
$$

繰り返し復調においては $\hat{d}_{k}(0)$ に対して硬判定を行い, シ

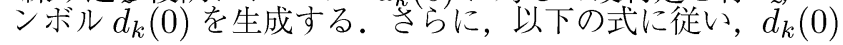
をプリコーディングすることによって，プリコーデッドシ ンボル $\tilde{D}_{n}(0)$ を生成する。

$$
\tilde{D}_{n}(0)=\sum_{k=0}^{N-1} u_{n, k} \tilde{d}_{k}(0)
$$

このようにして生成された $\tilde{D}_{n}(0)$ と $\hat{D}_{n}(0)$ を用いて，以 下の式に従って, 新たなプリコーデッドシシボル $\hat{D}_{n}(1)$ を 生成する。

$$
\hat{D}_{n}(1)= \begin{cases}\tilde{D}_{n}(0) & \text { if }\left|H_{n}\right|<T h r_{1} \\ \hat{D}_{n}(0) & \text { otherwise }\end{cases}
$$

(6) 式では,プリコーデッドシンボルの推定值 $\hat{D}_{n}(0)$ に対 して, 対応子る伝送路特性の絶対值がスレショルド值 $T h r_{1}$ より小さい場合に, $\tilde{D}_{n}(0)$ で置き換えを行うことによって, 新たなプリコーデッドシンボル列を生成している. 文献 10) に示されている通り, スレショルド值 $T h r_{1}$ を適切に設定 することによって, 置き換えを行う前のプリコーデッドシ ンボル列 $\hat{D}_{n}(0)$ よりも信号対雑音比の改善されたプリコー デッドシンボル列 $\hat{D}_{n}(1)$ を得ることができる。 その結果, $\hat{D}_{n}(1)$ を逆プリコーディングし, 判定することで, 誤り率 を改善することができる。ただし，スレショルドを伝送路 にあわせて理論的に適切に設定する方法は得られていない ので, 文献 10) ではスレショルドを小さな值から徐々に大 きくし, 繰り返し処理を行うことで特性の改善を行う方式 を提案している。文献では,

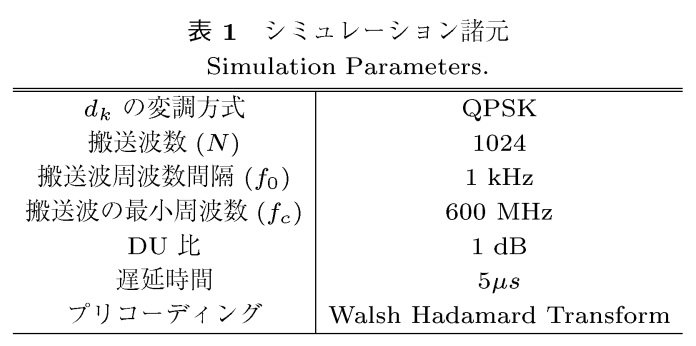

$$
\begin{aligned}
& H_{\text {min }}=\min \left\{\left|H_{0}\right|,\left|H_{1}\right|, \cdots,\left|H_{N-1}\right|\right\} \\
& H_{\text {ave }}=\sqrt{\frac{1}{N} \sum_{n=0}^{N-1}\left|H_{n}\right|^{2}}
\end{aligned}
$$

と定義し, これらを用いて $\Delta_{M}$ を以下の式で定義している.

$$
\Delta_{M}=\left(H_{a v e}-H_{m i n}\right) / M
$$

$\Delta_{M}$ を用いて, $i$ 回目の繰り返しでの処理に用いるスレショ ルド值を以下の式によって決定する。

$$
T h r_{i}=H_{\min }+i \Delta_{M} \quad i=1,2, \cdots
$$

ただし $M$ は正の整数であり， $\Delta_{M}$ の大きさを決めるパラ メータである。繰り返し処理では, スレショルド值 $T h r_{i}$ を 初期值から $\Delta_{M}$ ずつ大きくしながら $\left|H_{n}\right|$ との比較を行い, 比較結果に基づき, $\hat{D}_{n}(i-1)$ と再生されたプリコーデッ ドシンボル $\tilde{D}_{n}(i-1)$ とを入れ替えることによって $\hat{D}_{n}(i)$ を生成する処理を繰り返す。これによって，繰り返しに従 い, $\hat{d}_{k}(i)$ の信号対雑音比が向上し, 誤り率が改善される ことが確認されている。繰り返し処理に関する詳細は文献 10)を参照されたい.

ここで, 後の比較に用いるための一例として, 繰り返し 処理を行った場合のシミュレーション結果を示す.シミュ レーションで用いるパラメータは表 1 に示す通りであり, ここでは 2 波静的マルチパス伝送路を仮定している。また， 伝送路特性は既知であるものとしている。パラメータの一 つである DU 比は，遅延波の平均電力に対する直接波の平 均電力の比を表わす.プリコーデッド OFDM は, 劣悪な マルチパス環境下での特性を改善することを目的としてお り, DU 比が $1 \mathrm{~dB}$ のマルチパス環境下での特性について以 降評価していく.

図 1 に (9) 式の $M$ の值を変えて繰り返し処理を行った 場合の BER 特性を示す. 横軸の值は繰り返し回数に対応 するスレショルド值を表し, 対応する繰り返し回数の時点 で達成される BERを縦軸にプロットしている。横軸のス レショルド值は, 伝送路の最小振幅值を 0 , 平均振幅值を 1 とした值を基準として正規化されたスレショルド值である (以降の図中では横軸名は’ Normalized Threshold Value’ と標記している）。また, 以下の議論で用いられているス レショルド值はすべてこの基準に基づく值である，横軸は 最大 2 までとし，その範囲内でスレショルドの值を変えて 繰り返しを行った結果を示している．各曲線で $\Delta_{M}$ の值が 


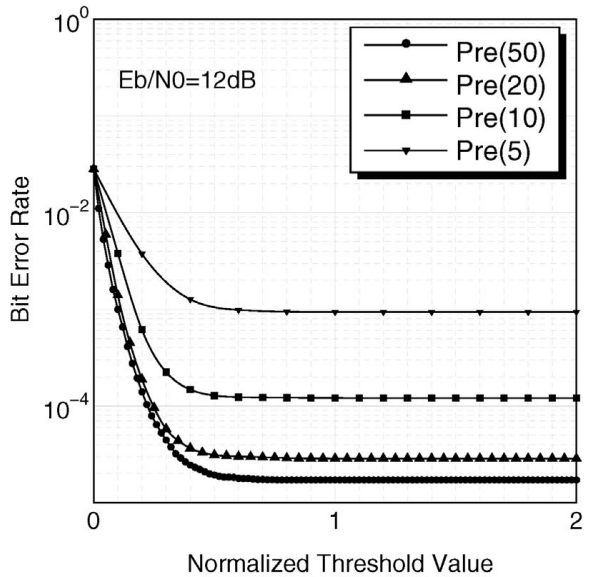

図 1 繰り返し回数に対する BER 特性 $\left(E_{b} / N_{0}=12 \mathrm{~dB}\right)$ BER performance against the number of iteration $\left(E_{b} / N_{0}=\right.$ $12 \mathrm{~dB})$.

異なるため, 図の範囲内でプロットされるシンボルの数は 異なる．また，図中の' Pre(数值)'などの標記は $M$ の值 として括弧内の数值を用いたことを表す.

図 1 の例のように, 繰り返し処理を行うことによって大 きな特性の改善が可能である。ただし，図に示すとおり，あ る程度の繰り返し回数で改善できなくなり, $M / 2$ 回程度の 繰り返しで最小值が得られることがわかる.

\section{3. 畳み込み符号化プリコーデッド OFDM}

2 章で示したように，プリコーデット OFDM 信号の繰 り返し復調を行うことで，大きな特性の改善を行うことが 可能であることが先行研究によって示されている. 本論文 では，上記のプリコーデッド OFDM の繰り返し復調方式 に，誤り訂正符号を組合せることによってさらにBER 特 性の改善を行う方式を提案し，その特性を評価する。本論 文では誤り訂正符号として, 符号化に畳み込み符号, 復号 にビタビ復号を用いる。助み込み符号を用いる理由は，プ リコーディング後の誤りパターンはランダム誤りになるた め, ランダム䛊りに強い冨み込み符号が適していると考元 られるためである。また，ビ夕ビ復号により最尤復号が可 能であり, 特性の向上が期待できる. 以下に本論文で検討 した方式の構成を説明する。

送信側では, 盢み込み符号で符号化したデータシンボル に対してプリコーディングを行う。本論文で検討を行う送 信器の構成を図 2 に示す。

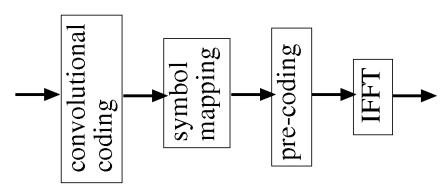

図 2 䛊り訂正符号を適用したプリコーデッド OFDM 送信機 の構成

Structure of the pre-coded OFDM Transmitter with convolutional coding.
受信機では， 2 章で説明した繰り返し処理によって復調 を行うことが可能であるが，データシンボルの信号対雑音 比の改善効果は, 硬判定後のデータシンボルに誤りが少な いほど大きくなると考えられる，そこで，硬判定後のデー タシンボルを再プリコーディングしてプリコーデッドシン ボルを生成する直前に，誤り訂正を行うことによって，よ り信頼性の高いプリコーデッドシンボルを再生し, 繰り返 し処理を行うことを提案する。これによって，特性をさら に向上できると考えられる，本論文では，誤り訂正処理の 適用方式として以下の二通りの方式について検討を行う.

第一の方式は, 従来の繰り返し処理によって復調された データシンボルに対して, 最後に誤り訂正処理を行う方式 である。この方式では, 受信された信号に対して 2 章で説 明した方式に従い繰り返し復調処理が行われ，指定された 繰り返し回数の繰り返し処理の後に得られるデータシンボ ルに対してビタビ復号を行う方式であり，誤り訂正処理は 繰り返し処理のループ内には含まれていない.

第二の方式は，データシンボルを硬判定しプリコーデッ ドシンボルを再生成する際に誤り訂正を行うことによって, より信号対雑音比の高いプリコーデッドシンボルを生成し, 繰り返し処理を行うものである。この方式では繰り返しご とに, データシンボル $\hat{d}_{k}(i)$ もしくはその硬判定值 $\tilde{d}_{k}(i)$ に 対してビタビ復号を行い，より信頼性の高いデータシンボ ルを生成する. ビ夕ビ復号器への入力は $\hat{d}_{k}(i), \tilde{d}_{k}(i)$ のい ずれを用いることも可能であり，前者を入力とする場合が 軟判定ビ夕ビ復号であり，後者を入力とする場合が硬判定 ビタビ復号である。ビタビ復号によってデータの誤りを訂 正し, 再び鳁み込久符号化を行って生成されたデータシン ボルをプリコーディングすることで, 信号対雑音比の改善 されたプリコーデッドシンボルが生成されることが期待で きる。これを用いて繰り返し処理を同様に行っていく。こ の方式では，繰り返しごとにビタビ復号が行われることに なる．また，最後にデータシンボルを復号するためにもう 一度ビ夕ビ復号を行うので, $i$ 回繰り返し処理を行う場合 $i+1$ 回のビ夕ビ復号処理が行われる. 本方式の構成を図 3 に示す.

以上のように本論文では, 誤り訂正符号の復号処理をプ リコーデッド OFDM 信号の繰り返し処理に組合せた方式 を提案しについて解析を行い有効性を示す. 誤り訂正処理 の繰り返し処理との組合せ方式として, 誤り訂正処理を繰 り返し処理のループ内に含めない場合と, 繰り返し処理の ループ内に含めた場合とについてその特性を比較検討する。 誤り訂正処理を繰り返し処理のループ内に含めることによっ て, 信号対雑音比の向上したプリコーデッドシンボルが再 生され, 繰り返し処理特性の更なる向上が期待できる.

\section{4. 特 性 評 価}

本章では，誤り訂正符号化プリコーデッド OFDM の特 性評価を行う。シミュレーションのパラメー夕は図 1 の結 


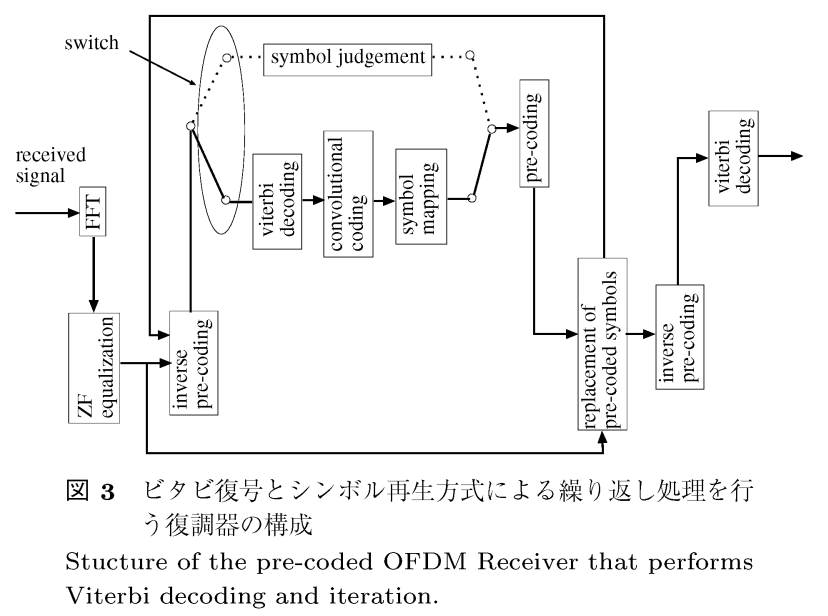

果を得る場合に使用したものと同様に，表 1 に示したもの を用いる。また，伝送路の特性は同様に既知であるものと する。これらのパラメータは以降のすべてのシミュレーショ ンに適用される。

本論文のシミュレーションでは畳み込み符号として, デ ジタル放送の規格である ISDB-T や無線 LAN などの多く の標準システムで採用されている，拘束長 7 , 符号化率 $1 / 2$ の畳み込々符号を用いた ${ }^{11)}$. 本論文で用いた符号は一例で あり，その他の構成の畳み込み符号を用いた場合も特性の 向上を図ることが可能なことが確認されている。本論文で は実例は示さないが, 種々の畳み込み符号の適用が期待で きる。

図 4 に 2 波静的マルチパス環境で，シンボル入れ替えを 行わないプリコーディングと畳み込み符号とビ夕ビ復号の 軟判定を組合せたときの特性を示す。

図中の表記に扔いて, 'w/o Pre'はプリコーディングを行 わない通常の OFDM の特性を表し, 'Pre'はプリコーディン グを行ったときの結果を表す。また, 'w/o Pre Viterbi' は通 常の OFDM 伝送にビタビ復号を組合せた結果であり, 'Pre Viterbi'はプリコーディングとビタビ復号を組合せた結果 である。ここで'w/o Pre Viterbi' の結果はビ夕ビ復号の 効果を高めるために, 周波数インタリーブを含んだ結果と なっている. 'Pre Viterbi' では, 周波数インタリーブを含 んでいないが，これはプリコーデイングを行うことで誤り パターンはランダムとなるので，インタリーブの効果は得 られないためである。

図 4 の結果より, ビ夕ビ復号のみを組合せることで, BER 特性が $10^{-5}$ で約 $11 \mathrm{~dB}$ の符号化利得が得られる。ささらにプ リコーディングと共に組合せることで, さらに $4 \mathrm{~dB}$ の改善 が得られた。通常のプリコーディング伝送と比べても $5 \mathrm{~dB}$ の符号化利得が得られた。しかしビ夕ビ復号を用いている ため $E_{b} / N_{0}$ の低い, $E_{b} / N_{0}<11 \mathrm{~dB}$ では通常の OFDM 伝 送よりも特性は劣化してしまう。

次にシンボル入れ替えと組合せた方式についての結果を 示す. 図 5 にシンボル入れ替えを行い，プリコーディング

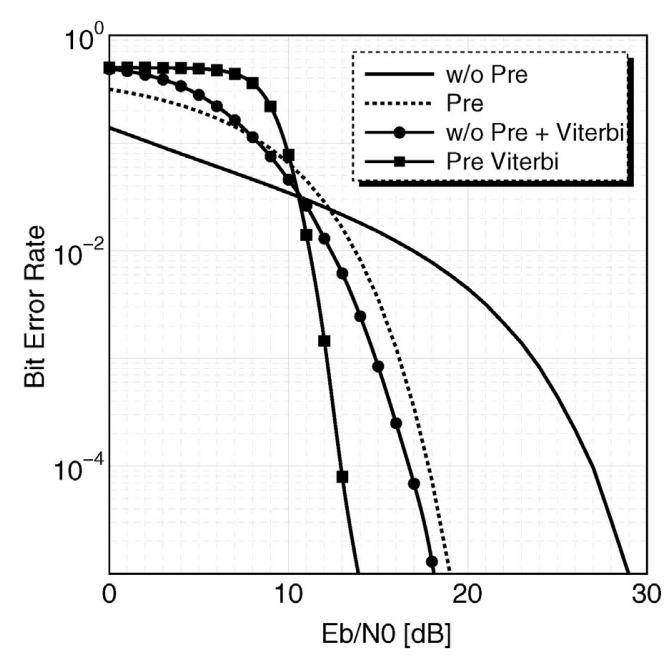

図 4 畳み込み符号化プリコーデッド OFDM の $E_{b} / N_{0}$-BER 特性 (軟判定)

$E_{b} / N_{0}$-BER performance of the pre-coded OFDM with convolutional coding(Soft Decision).

と睍み込み符号とビタビ復号を組合せたときの特性を示 す．ここで，一つめの組合せ方式である，シンボル入れ替 えを行ったあと, 最後の一度のみビ夕ビ復号を行ったもの を'Scheme A'とする。そして，二つめの組合せ方式であ る, シンボル入れ替え毎に, ビタビ復号と畳み込久符号化を 行ったものを'Scheme B' とする。すなわち図中の'Scheme A $\operatorname{Thr}(0.2)$ 'はスレショルド值を 0.2 として一度だけシン ボル入れ替えを行った後，最後にビ夕ビ復号を行ったとき の結果である。そして'Scheme B $\operatorname{Thr}(0.2)^{\prime}$ は, 誤り訂正 を行いシンボル再生をした後に，スレショルド值を 0.2 と して一度だけシンボル入れ替えを行った後, 再びビ夕ビ復 号を行ったときの結果である。

図 5 の結果より, シンボル入れ替えを行うことで， Scheme A', 'Scheme B' どちらの場合でも特性が改善 されている。特に'Scheme B' のようにシンボル入れ替え毎 にビタビ復号を行った方が'Scheme A'に比べ，BER 特性 が $10^{-5}$ で約 $1 \mathrm{~dB}$ の改善がある。

図 6 にスレショルド值に対する BER 特性を示す。図 6 の結果より，BER を最小にする最適なスレショルド值は $E_{b} / N_{0}$ に依存することがわかる。ここでは $E_{b} / N_{0}$ が大き くなるほど，最適なスレショルド值は小さくとったほうが 効果的であることがわかる。これは前述と同様で, $E_{b} / N_{0}$ が大きくなるほど，雑音成分は小さくなるので，スレショル ドの值が大きいと良好なシンボルまで入れ替わってしまう ためである。また最適なスレショルド值辺りでは'Scheme B'の方が'Scheme A'に比べて特性の改善度が高いことが わかる、スレショルドがある程度大きくなると，'Scheme A'の方が' Scheme B' より特性が良くなっているが，この 理由については解明するための解析を現在引き続き行って 


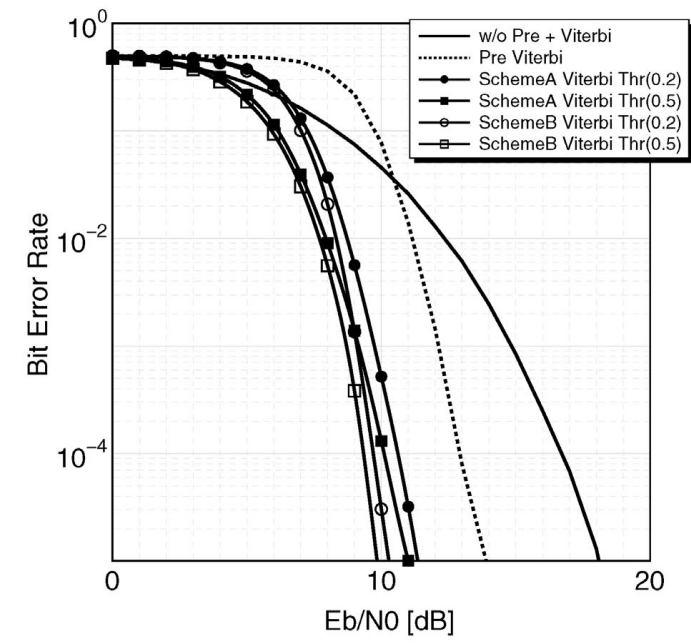

図 5 盢み込み符号化プリコーデッド OFDM において 1 回シ ンボル入れ替えを行ったときの $E_{b} / N_{0}-\mathrm{BER}$ 特性 (軟 判定)

$E_{b} / N_{0}$-BER performance of the pre-coded OFDM with convolutional coding after single iteration(Soft Decision).

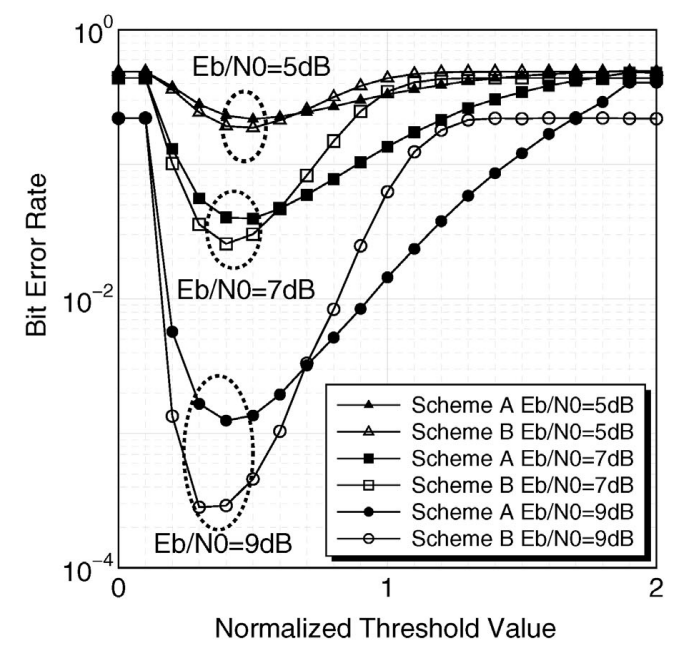

図 61 回シンボル入れ替えを行う場合の Threshold-BER 特 性 (軟判定)

Threshold-BER performance for single iteration(Soft Decision).

いる.しかしながら，後で述べるように，本論文における繰 り返し復調方式に扔いては，特性改善が行われるスレショ ルドの初期值は，この值よりお抢む敉低い值から開始し， 徐々にスレショルドを上げて繰り返し処理を行うため, 常 に’Scheme B' のほうが良い特性を得られることが確認され ている.

図 7 に誤り訂正符号にプリコーデイングの繰り返し復 調を組合せた場合の BER 特性を示す. 図中の'Scheme A Pre(5)'はシンボル入れ替えを 5 回行った後, 最後にビタビ 復号を一度だけ行ったときの結果である。そして'Scheme B Pre (5)' は, ビタビ復号と睍み込从符号化をシンボル再 生毎に行う。この場合はシンボル再生と誤り訂正が 5 回繰 り返されたときの結果を示している。

図 7 より, 繰り返し復調と誤り訂正を組合せにおいても,

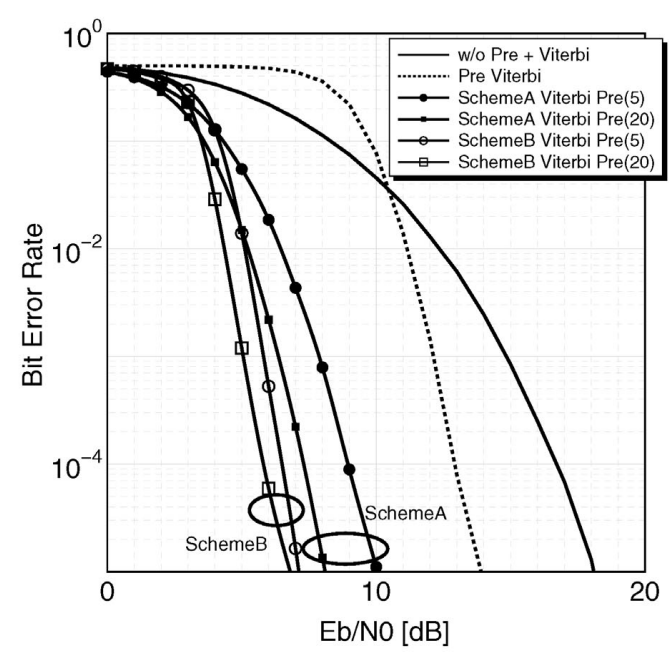

図 7 畳み込み符号化プリコーデッド OFDM の繰り返し復調 時の $E_{b} / N_{0}$-BER 特性 (軟判定)

$E_{b} / N_{0}$-BER performance of the pre-coded OFDM with convolutional coding under the case where iterative decoding is performed(Soft Decision).

Scheme B'のように繰り返しビ夕ビ復号を適応させた結果 の方が, 繰り返し回数 5 回の場合'Scheme A'よりも BER 特性が $10^{-5}$ で約 $3 \mathrm{~dB}$ の改善がある。また 20 回繰り返し た場合, 'Scheme A Pre(20)'は'Scheme A Pre(5)' と比べ て約 $2 \mathrm{~dB}$ の改善はあるが, 'Scheme B Pre(5)'よりも特性 は劣っている.一方, 'Scheme B Pre(20)' では, 'Scheme B Pre(5)' と比較して BER 特性の改善は少ない。すなわ ち, ' Scheme B'のようにビ夕ビ復号も繰り返す方式は，少 ない繰り返し回数でも充分に特性の改善が可能である.

これまでの図 7 までに用いたビ夕ビ復号は全て軟判定で ある. 次に, 図 8 , 図 9 にビ夕ビ復号に軟判定, 硬判定を 用いたときのスレショルドに対する BER 特性を示す。図 中の表記は' SchemeA(x)'は’Scheme A'での繰り返し復 調方式に拈ける結果を示して抢り, 'x'は (9) 式の $M$ の值 を示している。'SchemeB(x)'に関しても同様で, Scheme B(x)'は’Scheme B'での繰り返し復調方式に扔ける結果を 示している.

図 8 の結果より，軟判定で繰り返したとき'Scheme A'で はスレショルド值が 0.6 あたりを越えると特性の劣化が生 じている。一方'Scheme B'では繰り返しすぎても特性の劣 化は見られない。また図 9 の結果より, 硬判定で繰り返し たときには'Scheme A', 'Scheme B' 共にスレショルド值 が 0.6 あたりで特性は収束し，劣化は見られない。

図 10 に図 8, 図 9 に打ける'Scheme A'での特性のみを 重ねて示す。すなわち'Scheme A'での軟判定と硬判定での スレショルド值に対する BER 特性の比較を示す.

図 10 の結果より, 'Scheme A'に扔いて軟判定ビタビ復 号を行う場合スレショルド值が 0 より 0.5 付近までは繰り返 しに伴いBER が改善されているが，スレショルドが 0.5 付 近を越えて繰り返しを行っていくと繰り返しとともにBER 


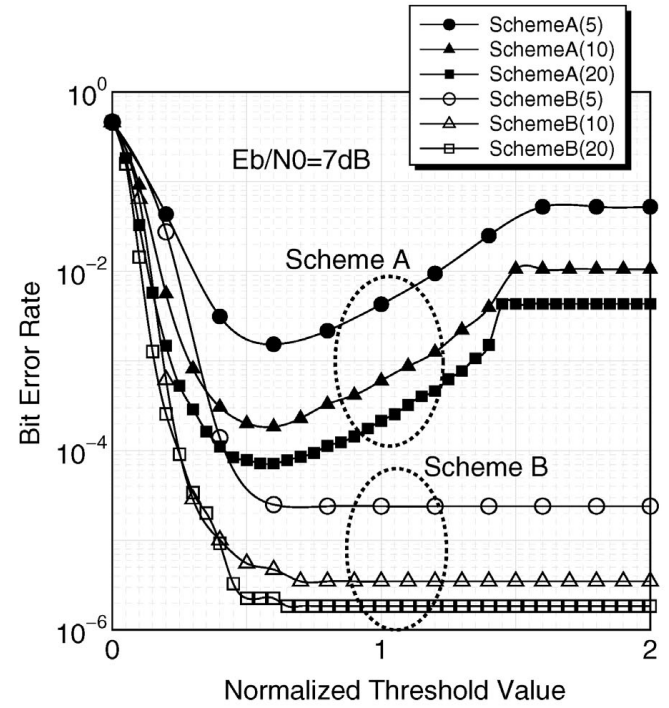

図8 軟判定を行ったときの繰り返し毎の BER 特性 $\left(E_{b} / N_{0}=7 \mathrm{~dB}\right)$

BER performance against the number of iteration with soft decision Viterbi Decoding $\left(E_{b} / N_{0}=7 \mathrm{~dB}\right)$.

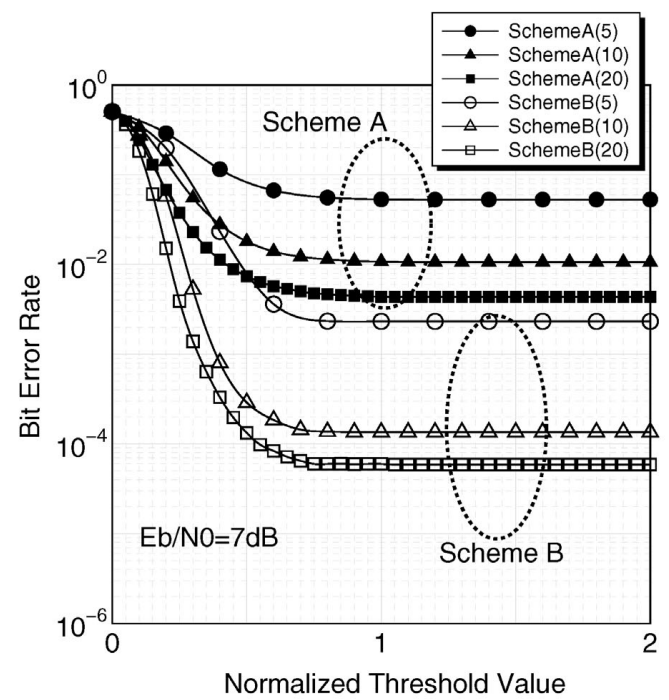

図 9 硬判定を行ったときの繰り返し毎の BER 特性 $\left(E_{b} / N_{0}=7 \mathrm{~dB}\right)$

BER performance against the number of iteration with hard decision Viterbi Decoding $\left(E_{b} / N_{0}=7 \mathrm{~dB}\right)$.

特性の改善が得られなくなり, 最終的には硬判定ビ夕ビ復 号の場合と同等になってしまうことがわかる.この理由につ いて考察を行う。硬判定ビタビ復号を使用した場合復号器 にはデータシンボルを判定した後の 2 值のデータが入力さ れ，八ミング距離に基づく誤り訂正が行われる。したがっ て, ビ夕ビ復号器入力前の BER に対応した誤りの改善が なされる. 図 1 に誤り訂正を含まない繰り返し処理の BER 特性を示したが，硬判定ビタビ復号処理による誤り訂正後 の誤り率は, 図 1 で達成されているビット誤り率に対して, 符号化利得分の特性改善がなされたものである。(ただし， 図 1 の例は図 10 の例と $E_{b} / N_{0}$ は異なっている.）したがっ て, 硬判定の場合は図 10 のような右下がりの結果が図 2

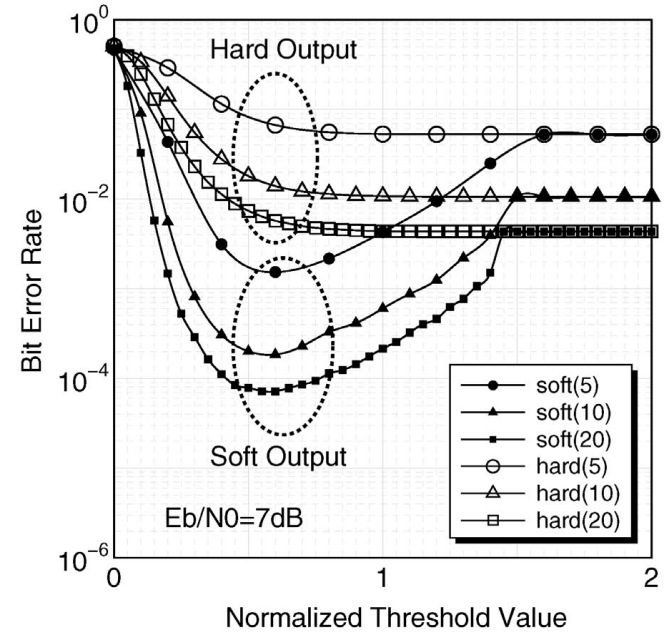

図 10 軟判定と硬判定との繰り返し毎の BER 特性 $\left(E_{b} / N_{0}=7 \mathrm{~dB}\right)($ Scheme A)

BER comparison between soft decision and hard decision Viterbi decodings against the number of iterations $\left(E_{b} / N_{0}=7 \mathrm{~dB}\right)($ Scheme A).

の場合と同様に得られることになる。これに対して，軟判 定ビ夕ビ復号の場合は，2 值データではなく，硬判定前の QPSK シンボルから得られる連続的な IQ データ（以下ソ フト值と呼ぶ）が入力されユークリッド距離に基づく復号 が行われる。軟判定復号の場合は硬判定復号よりも一般的 に特性は向上し，図 10 でも概称そのようになっているが, スレショルドが 0.5 付近を越えて繰り返しを重ねると改善度 が劣化し最終的には硬判定のものと同等になる。このよう な結果は, 繰り返し処理に伴うビ夕ビ復号器への入力デー 夕の変化によって生じると考えられる。繰り返し処理に扔 いては，データシンボルを硬判定しそれらを再変調するこ とによって，プリコーデッドシンボルを生成しスレショル ドに基づき受信されたシンボルと入れ替えを行い，新たな プリコーデッドシンボル列を生成し処理をさらに進めてい く。このとき，新たに生成されたプリコーデッドシンボル 列には，ソフト值である受信プリコーデッドシンボルと硬 判定データから生成されるプリコードデッドシンボルの両 者が含まれている。プリコーデッドシンボル全体に対する 硬判定後のデータシンボル（以下ハード值と呼ぶ）成分の 割合は繰り返し回数が増えるほど（スレショルドが大きく なるほど）増加し，すべてのプリコーデッドシンボルが入 れ替えられると，すべてハード值のみになってしまう。し たがって，逆プリコーディング後のデータシンボルもソフ 卜值とハード值が混在した形となり，それに対して軟判定 ビタビ復号が行われることになる。軟判定復号では，ソフ 卜值が多く含まれるほうが誤りの改善度は大きいため，図 10 でスレショルドが 0.5 付近を越えて繰り返しを進めると, ビタビ復号器への入力データにおけるハード值の割合が増 加し，最終的にはすべてハード值で構成されるデータが入 力され，硬判定ビ夕ビ復号の場合と同等の結果となる．以 上のような理由から，軟判定ビ夕ビ復号器を用いた場合は， 
ソフト值の含まれる割合と，繰り返し回数との関係で 0.5 付近において最も BER 特性が改善されているものと考え られる。したがって, 'Scheme A'に軟判定ビ夕ビ復号器を 用いた場合は, 適切な回数で繰り返しを打ち切る必要があ る.この最適值の導出については現在理論的に解析中であ り, 今後の課題である.

\section{5.むすび}

本論文では，極めて厳しいマルチパス環境下において OFDM の特性を改善することを目的として，プリコーデッ ド OFDM の繰り返し復調方式に畳み込み符号を組合せた 方式を提案し，シミュレーションによる評価を行った．誤 り訂正符号には，畳み込み符号とビ夕ビ復号を用いた。そ の結果, 誤り訂正符号を組合せることで, 壳長ビットによ る伝送速度の低下はあるが，従来大きな特性改善には多数 回の繰り返し処理が必要であったが, 適切に誤り訂正符号 を組み合わせることで, 少ない繰り返し回数でも, 良好な 特性を得ることが可能であることが確認された。

特に，プリコーディングを繰り返す毎に誤り訂正も繰り 返した方式 (Scheme B) は, 繰り返し復調方式の最後に一 度だけ誤り訂正を行った方式 (Scheme A) に比べて, 良好 な特性が得られた. 同じ 5 回のプリコーディングの繰り返 し復調でも'Scheme B' では'Scheme A'ょりもDU 比が $1 \mathrm{~dB}$ の非常に厳しいマルチパス環境下で BER 特性が $10^{-5}$ で約 $3 \mathrm{~dB}$ の改善できることを示した。

'Scheme B' の場合は, 繰り返し回数が 5 回程度でも大き な特性の改善が可能であるため, 従来方式よりもプリコー ディングの繰り返し回数を減らすことができる。また, 繰 り返しをある程度まで繰り返すと特性の改善はなされなく なるので, 適切な繰り返し回数で打ち切れば余分な処理は 不要になる。仮に大きなスレショルド值まで繰り返し過ぎ てしまっても'Scheme B' の場合は BER 特性が劣化するこ とがないことも大きな利点である。

'Scheme A'は, ビ夕ビ復号を 1 回行うだけの構成であ り, ある程度の特性改善効果もあるため, ハードウェアの制 限が厳しく, 性能への要求がある程度高くない場合には充 分に適用可能な方式であると考えられる. しかしながら, 図 8 に示したように, 'Scheme A'では繰り返しの進行に伴い スレショルド大きくなりすぎると返って特性の劣化が生じ る、したがって, 最適なスレショルドで繰り返しを打ち切 る必要がある。最適なスレショルド定めた上で, 'Scheme A'はハードウェアの制約が厳しいときに適用し, 'Scheme B'はハードウェアが大きくなっても性能向上が必要な場合 に使用することが考えられる。

今後の課題として, 最適なスレショルド值の理論的な決 定方法の検討. また今回, 誤り訂正符号として, 畳み込み 符号とビタビ復号との組合せで検討を行ったが, 別の符号 器との組合せや, 実際に伝送路特性の推定を行った場合の 性能評価が必要となる。

\section{〔文献〕}

1) R. W. Chang and R. A. Gabby, "A Theoretical Study of Performance of an Orthogonal Multiplexing Data Transmission Scheme",IEEE Trans.Comm., COM-16, pp.529-540 (1968)

2) S. B. Weinstein and P. W. Ebert, "Data Transmission by Frequency-Division Multiplexing using the Discrete Fourier Transform", IEEE Trans.Comm., COM-19, pp.628-634 (1971)

3) B. Hirosaki, "An Analysis of Automatic Equalizer for Orthogonally Multiplexed QAM System", IEEE Trans.Comm., COM-28, pp.73-83 (1980)

4) B. Le Floch, M. Alard and C. Berrou, "Coded Othogonal Frequency Division Multiplex", Proceedings of the IEEE, 83, 6, pp.982-996 (1995)

5) K. Kyomen, Y. Owaki, M. Itami and K. Itoh, "A Study on Data spread OFDM Scheme applying MAP Decoding", Proceedings of PIMRC 2003, 2, pp.1085-1089 (2003)

6) C. Tepedelenlioglu, "Maximum Multipath Diversity With Linear Equalization in Precoded OFDM Systems", IEEE Trans. Inform Theory, 50, 1, pp.232-235 (2004)

7) S. Kanamori, M. Fujii, M. Itami and K. Itoh, "A Study on Subcarrier Power and Phase Control of Data Spread OFDM with Transmission Diversity", Proceedings of the 7th International Symposium on Wireless Personal Multimedia Communications, 2, pp.175-179 (2004)

8) S. Tamura, M. Fujii, M. Itami and K. Itoh, "Iterative Detection of Precoded OFDM under Frequency Selective Channels", Proceedings of PIMRC 2005, 5, pp.2489-2494 (2005)

9) H. Miyasaka, H. Horii, S. Tamura, M. Fujii, M. Itami and K. Itoh, "An Iterative Detection of Pre-Coded OFDM combined with Convolutional Code", Proceedings of PIMRC 2007, pp.24892494 (2007)

10）堀居弘幸, 宮坂宏明, 田村明香, 藤井雅弘, 伊丹誠, 伊藤紘二 “周波数選 択性フエーディング環境下に㧍けるプリコーデッド OFDM の繰り返し 復調方式”, 映情学誌, 62, 5, pp.755-762 (2008)

11）河内健 “地上デジタルテレビジョン放送” 株式会社トリケップス (2002)

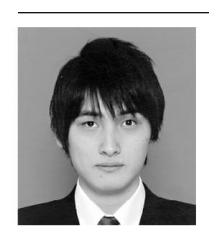

宮坂 䆖明 2007 年, 東京理科大学基礎工学部電 子鬼用工学科卒業. 現在同大学院基礎工学研究科電子応 用工学専攻修士課程在籍. OFDM の研究に従事.

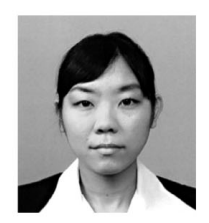

増田陽子 2009 年, 東京理科大学基礎工学部電 子応用工学科卒業. 現在同大学院基礎工学研究科電子応 用工学専攻修上課程在籍. OFDM の研究に従事.

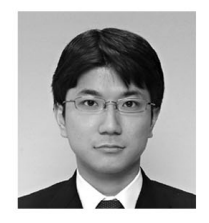

大野 光平 2002 年, 明治大学理工学部電子通信工 学科卒業. 2004 年, 同大学大学院理工学研究科博士前期 課程修了, 2007 年, 同大学大学院理工学研究科博士後期 課程修了. 同年, 東京理科大学基礎工学部電子忍用工学 科助教. 現在に至る。 2004 年, 横須賀リサーチパーク (YRP) アワード奨励賞. 通信方式, 特に広带域無線技術 などの研究に従事. 博士 (工学).

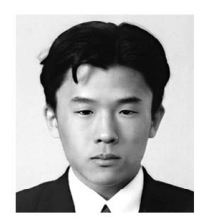

貿滕井 雅弘 1998 年, 東京理科大学基礎工学部電 子㐫用工学科卒業. 2003 年, 同大学大学院博士課程修 了. 同年, 東京理科大学基礎工学部電子応用工学科助手. 2006 年, 宇都宮大学工学部助手. 2008 年, 宇都宮大学 大学院工学研究科助教. 現在に至る. 通信方式, 信号処 理の研究に従事. 工学博士.

伊きみ 站と 1984 年, 東京大学工学部電子工学科 卒業. 1989 年, 同大学大学院工学系研究科電気工学専攻 博士課程修了. 同年, 東京理科大学基礎工学部電子応用 工学科講師. 2000 年, 同大学助教授. 現在に至る. 通信 方式, 信号処理, 教育工学などの研究に従事. 工学博士. 正会員. 